\title{
İbn Haldun'un Asabiyeti: Bir Kavramın Sosyolojik İzdüşümleri
}

\author{
Behçet BATUR* iD
}

\begin{abstract}
ÖZ
İbn Haldun'un sosyal bilimsel analizinin temel kavramı kuşkusuz asabiyet kavramıdır. İbn Haldun bu kavramı Mukaddime adlı eserinde oldukça geniş bir anlam yelpazesi içerisinde kullanmaktadır. Onun açısından bakıldığında bu kavram, toplumu oluşturan en küçük gruptan küresel ölçekteki en büyük sosyal birime kadar geniş bir anlamsal içeriğe sahiptir. Asabiyet, özünde toplumsal birimlerin birleştiricisi ve ortak bilinci, sosyal yardımlaşma, dayanışma ile savunma duygu ve bilinci olmakla birlikte bu kavramın sahip olduğu geniş anlamın sosyolojik izdüşümleri vardır. Bunlar, temel grup (aile) bilinci olarak asabiyet, milli bilinç olarak asabiyet, dini (ideolojik) bilinç olarak asabiyet, siyasi bilinç olarak asabiyet, küresel bilinç olarak asabiyet, toplumsal düzenin sağlayıcısı olarak asabiyet ve toplumsal değişmenin kaynağı olarak asabiyet. Her bir asabiyet formunun özerk bir yapısı bulunmakla birlikte toplumda faaliyet gösteren tüm asabiyetler karşılıklı etkileşim ve eşgüdüm halindedirler. Bu çalışmada asabiyete ilişkin olarak yapılan tipolojik çözümleme çağdaş toplumsal hayatın çözümlenmesi ve anlaşılması noktasında oldukça yararlı bir analitik işleve sahip olabilir.
\end{abstract}

Anahtar Kelimeler: İbn Haldun, Asabiyet, Kolektif bilinç, Grup, Toplum

\section{The Asabiyya of Ibn Khaldun: Sociological Projections of a Concept}

\begin{abstract}
The basic concept of Ibn Khaldun's social scientific analysis is undoubtedly the concept of asabiyya. Ibn Khaldun uses this concept in a wide range of meanings in his work named Mukaddime. From his point of view, this concept has a wide semantic content from the smallest group forming the society to the largest social unit on a global scale. Asabiyyah is in essence the unifying and common consciousness of social units, social assistance, solidarity and defense feeling and consciousness, but there are sociological projections of the broad meaning of this concept. These are asabiyya as the main group (family) consciousness, asabiyya as national consciousness, asabiyya as religious (ideological) consciousness, asabiyya as political consciousness, a sabiyya as the global consciousness, asabiyya as the provider of the social order and asabiyya as the source of social change. Although each form of asabiyya has an autonomous structure, all asabiyyahs operating in the society are in mutual interaction and coordination. The typological analysis of asabiyya in this study can have a very useful analytical function in analyzing and understanding contemporary social life.
\end{abstract}

Keywords: Ibn Khaldun, Asabiyyah, Collective consciousness, Group, Society

\section{Giriş}

Toplumsal olguların ve olayların anlaşılmasının bilimsel yolu öncelikle empirik verilerden hareketle oluşturulmuş kavram oluşturmaktan geçmektedir. Bu açıdan modern sosyoloji toplumsal olguların anlaşılması ve açıklanması noktasında çeşitli kavram, kuram ve yaklaşımlar geliştirmiştir. Söz gelimi toplum, grup, kurum, ortak bilinç, kültür, din vb. tüm bu sosyal bilimsel kavramların nihai hedefi içinde bulunduğumuz ve adına toplum dediğimiz olgunun anlaşılması ve açıklanmasıdır.

Sosyal bilimsel tüm kavramlar sürekli olarak yeniden tanımlanabilir ve onlara yeni anlamlar yüklenebilir. Burada asabiyet kavramının Mukaddime adlı eserde nasıl farklı anlam ve bağlamlarda kullanıldığına değinilecektir. $\mathrm{Bu}$ çalışmanın amacı İbn Haldun'un asabiyet kavramının sosyolojik izdüşümlerinden hareketle bir asabiyet tipolojisi ortaya koymaya çalışmaktur.

İbn Haldun'da toplumsal dayanışmanın esasını asabiyet oluşturmaktadır. Kendisinin de belirttiği gibi, "Birbirini koruma, savunma ve hak arama, ancak asabiyetle mümkün olabilir. Bu, ortaklaşa yapılan her çeşit toplumsal faaliyet için de geçerlidir” (İbn Haldun, 2015, s. 350). Her türlü toplumsal yapı, dayanışma ve hareketin temelini asabiyet oluşturmaktadır. İbn Halduncu asabiyet kavramı sadece belirli bir toplumun belirli bir boyutunu açıklamaz. Bu kavram sosyolojinin anahtar ve merkezi kavramı olarak toplumsal hayatın tüm alanlarını kapsamaktadır. Dolayısıyla her türlü grupsal yapılanmanın ve eylemin ana aktörü asabiyettir. Asabiyet, toplumda farklı şekillerde tezahür edebilecek, olumsuz veya olumlu, eğilimleri görülebilecek nitelikte oldukça canlı bir kavramdır (Gültekin, 2016, s. 292). Bu yüzden asabiyet teorisi

\footnotetext{
* Dr. Öğr. Üyesi, Gaziantep İslam Bilim ve Teknoloji Üniversitesi, behcetbatur@yahoo.com
} Makalenin Gönderim Tarihi: 24.03.2021; Makalenin Kabul Tarihi: 28.07.2021 
oldukça geniş bir etki alanına sahip ve çok sayıda bileşeni olan bir teoridir (Demircioğlu, 2015, s. 235). İbn Haldun'un farklı anlamlar yükleyerek asabiyeti yeniden tanımladığı konusunda uzmanlar hemfikirdir (Kayapinar, 2006, s. 108). O, asabiyeti bazen faydasına, bazen de amacına göre tarif eder, bunun kaynağını gösterir, çeşitlerini belirlemeye çalısıır, özellikle önemine dikkat çeker (Uludağ, 2015, s. 76). İbn Haldun aile kurumundan başlayarak, topluluk, devlet sahibi ile devlet görevlilerinin oluşturduğu gruplar gibi çeşitli sosyal birimlerde farklı asabiyetlerin varlığını kabul eder. Böylece asabiyet, geniş anlamda bir toplumsallık ilkesi şeklinde ortaya çımaktadır (Arslan, 2014, s. 98-99).

İbn Haldun'un toplum kuramında önemli bir yeri olan asabiyet kavramı şüphesiz İbn Haldun’u araştıranların üzerinde en fazla inceleme yaptıkları kavramlardan biridir. Ancak onun asabiyete verdiği çok boyutlu anlam, bu kavramın modern sosyal bilimlerin kullandığ benzer kavramlarla birebir ifade edilmesinde bir takım zorluklar ortaya çıarabilmektedir. Çağdaş araştırmacılar bu kavramı genel olarak sosyal yardımlaşma veya dayanışma hissine dair kavramlarla açıklamaya çalışsalar da, bunun asabiyet kavraminın sadece bir boyutunu ifade ettiğini belirtmeliyiz (Hasanov, 2016, s. 1438).

Kavramın İslamiyet’ten önceki dönemde ifade ettiği “irkçılık veya kabilecilik" anlamları nedeniyle İslam kültüründe bu kavram, daha çok olumsuz bir kavram olarak değerlendirilmiş; özellikle Hz. Muhammed'in, kabilecilik anlamındaki asabiyeti katı bir dille eleştirmesi ve reddetmesi nedeniyle, Müslüman bilginler, asabiyeti bir erdemsizlik olarak yorumlamışlardır. İbn Haldun ise, bu sözcüğe olumlu bazı anlamlar yükleyerek, onu kendi tarih ve toplum teorisinde önemli bir yere oturtmuştur. Ancak İbn Haldun, asabiyet teriminin kendi teorisinde içerdiği anlamı açıça gösteren tek bir tanımını vermemiştir. Bu nedenle bazı araştırmacılar, bu kavramın Mukaddime'de grup duygusu, dayanışma bilinci, kabilecilik, kan bağı gibi kavramlardan biri ya da birkaçı için kullanıldığını ifade etmişlerdir (Kaynar \& Ak, 2018, s. 186). Dolayısıyla bu kavram belirli bir tanıma indirgenemez. İbn Haldun'da toplumu oluşturan temel faktör konumuna oturtulan bu kavram, toplumun her türlü ideolojik, siyasi, dini, mesleki, milli, ahlaki vb. bilinçlilik hallerine işaret eden, toplumsal düzen ve değişme dinamiklerinin temelinde bulunan merkezi bir kav ram olarak görülmektedir (Batur, 2019, s. 101).

İbn Haldun 14. yüzyllda yaşamış bir düşünür olarak 1377 yllında kaleme aldığı Kitab’ul-İber adlı eserinin Mukaddime kısmında toplumun anlaşılması ve açılanması noktasında oldukça çeşitli anlam ve fonksiyonlara sahip olan bir kavram üzerinde durmuştur: Asabiyet. İbn Haldun bu kavramı farklı toplumsal olgu ve olayların anlaşılmasında başarılı bir şekilde kullanmıştır. Burada İbn Haldun'un bakış açısından hareketle asabiyet kavramının toplumun anlaşılması noktasında sahip olduğu anlam ve fonksiyonların sosyolojik izdüşümleri üzerinde durulmaya çalş̧lacaktır.

\section{Temel Grup (Aile) Bilinci Olarak Asabiyet}

İbn Halduncu asabiyet kavramsallaştırmasının en temel özelliği sosyal dayanışma bilinci olmasıdır. Bu yönüyle kavram temel grup ruhu olarak karşımıza çımaktadır. Bunun sosyolojik izdüşümünü ise aileler ve akrabalık ilişkileri meydana getirmektedir. Başka bir ifadeyle asabiyet temelde kan ve soy bağına (nesep asabiyetine) dayanmaktadır. İbn Haldun bu hususu şöyle ifade etmektedir. "Asabiyetteki savunma ve mücadeleden kasdedilen konu, sadece soy bağıyla (nesep) tam olarak gerçekleşebilir. Çünkü yardımlaşma durumu yakın akraba arasında, dağılma hali ise yabancı ve uzak olanlar arasında görülür” (İbn Haldun, 2015, s. 412-413).

Görüldüğü gibi asabiyet kavramının en doğal ve saf hali ailede ortaya çıkmaktadır. Bu açıdan aile kurumu toplumun ve asabiyetin temelidir denebilir. Her insan bir ailede doğmakta, doğduğu ailenin bakım ve himayesi altında büyümektedir. Böylece herkes ilk yardımlaşma ve dayanışma duygu, düşünce ve pratiğini ailede görmektedir. Bu açıdan aile, sosyal yardımlaşma ve dayanışmanın temel kurumu olmaktadır. Nesep asabiyeti toplumsal birlik ve dayanışmanın temeli olması hasebiyle hayati bir öneme sahiptir. Buna göre toplumun çekirdeği aile, temel dayanışma bilinci de nesep asabiyetidir. Diğer toplumsal birlikler dağılabilir, değişebilir fakat aile/soy bağı en sağlam ve kalıcı olan bağdır. Bir kişinin genel, daha genel, özel daha özel olmak üzere birçok asabiyetleri bulunabilir. Genele gidildikçe etkinliği azalan asabiyet özele gelindikçe güçlenir, etkinliği artar (Uludağ, 2015, s. 83). Buradan hareketle asabiyetin, akrabalık bağının uzak ve yakın oluşuna bağlı olarak farklı derecelerde olduğu söylenebilir. 
Eğer aradaki kan/soy bağı yakınsa, o kişi ya da kişilere duyulan yardım etme arzusu da o derece güçlü olur. Bu nedenle, bir kişinin akrabaları için duyduğu yakınlık duygusu, kendi ailesinden başlayarak suya atılmış taşın oluşturduğu halkalar misali yoğunluğunu kaybede kaybede mensubu olduğu ve gerilerde bir yerde aynı atadan geldiğini düşündüğü insanlardan oluşan en geniş grubun fertlerine varıncaya kadar yayılır (Kayapinar, 2006, s. 89).

Ailenin veya nesep asabiyetinin önem ve işlevine ilişkin olarak İbn Haldun şöyle bir çözümlemede bulunmaktadır:

"Çok azı istisna, insanlarda akrabalık ilişkisi doğal bir şeydir. Bu ilişkinin gereklerinden biri de gayrete gelerek, yardıma ihtiyaç duyan hısım ve akrabaların yardımlarına koşmaktır. Kuşkusuz ki, akrabası zarara uğrayan biri, bundan dolayı kendini zelil hisseder, bu durum da onun ağrina gider. Akrabamın maruz kaldığ haksızlıkları ve tehlikeleri önleyebilsem, diye temenni eder. $\mathrm{Bu}$, var olduklarnndan beri insanlarda doğal olarak var olan bir eğilim ve duygudur. Birbirinin yardımına koşanlar arasındaki soy bağı, birleşme ve kaynaşma meydana getirecek kadar çok yakınsa, aradaki bağ açık olur, demektir. Bu bağın soy olarak var ve açık oluşu yardımlaşmayı gerektirir”" (İbn Haldun, 2015, s. 334-335).

İbn Halduncu perspektiften bakıldığında aile, temel, evrensel ve zorunlu bir kurum olarak değerlendirilir. Sonuçta İbn Halduncu nesep asabiyeti kavramının sosyolojik izdüşümü aile grubu/kurumudur. Toplumun temel birimini aile ve birleştirici unsur olarak nesep asabiyeti oluştururken, toplumsal diğer birlik ve dayanışmanın temelini de yine asabiyet (sebep asabiyeti) oluşturmaktadır. Demek ki asabiyet başlangiçta temel grup ruhu ve bilinci olarak ortaya çımakta, akabinde diğer toplumsal birliklerde karşıllğını dolaylı olarak bulmaktadır.

İbn Haldun'a göre, asabiyetin temel işlevi sosyal yardımlaşma ve dayanışmayı sağlamasıdır. Buna karşıın hayatın zorluklarına karşı yardımlaşma ve dayanışmayı sağlayan asabiyetin somut bir gerçekliği bulunmamaktadır. Asabiyetin gerçekliği, yerine getirdiği sosyal yardımlaşma ve dayanışma duygu, düşünce ve pratiğidir. Bunların bulunmadığı bir yerde asabiyetten söz edilemez. Kendisinin de belirttiği gibi, "nesebin tek faydası, dayanışmayı gerektiren söz konusu kaynaşmadır. Böylece yardımlaşma ve imdada koşma durumu meydana gelir. Bundan başka soy bağına ihtiyaç yoktur. Çünkü soy bağı da vehmi (zanni, hayali, zihni) bir şeydir, herhangi bir gerçekliği yoktur" (İbn Haldun, 2015, s. 335). "Kan bağ1 (nesep) doğal bir şeyse de, sonuçta o da vehmidir. Kaynaşmanın meydana gelmesine neden olan husus ise, bir arada yaşama, birbirini savunma, uzun süren birliktelik, birlikte yetişme ve süt emme durumunun meydana getirdiği sosyal bağ ile hayatla ilgili olan durumlardan ibarettir” (İbn Haldun, 2015, s. 413).

İbn Haldun herhangi bir sosyal grubun sosyolojik açıdan grup sayılabilmesi için mutlak anlamda bir dayanışma ve aidiyet duygu ve düşüncesine sahip olması gerektiğini düşünür. Asabiyetin olmadığı insan toplulukları grup sayllamazlar. Dolayısıyla her türlü grup bilincini asabiyet oluşturmaktadır. Nesep asabiyetinin grup üyelerini içeride yardımlaşma halinde, dışarıya karşı da güçlü olmak üzere faaliyete geçiren bir nitelik taşıması gerektiğine inanan İbn Haldun, harekete geçirmeyen, pasif bir nesep asabiyetine sahip olan grupların gerçekte grup bile sayılamayacağını savunur (Hasanov, 2016, s. 1442). İbn Haldun'un sosyal dayanışma, ortak geçmiş bilinci, kuşaklararası iletişim vb. düşünceleri kapsayan ve hepsi de asabiyete çıan oldukça çok boyutlu bir toplum teorisi geliştirdiği görülmektedir (Hasanov, 2016, s. 1445).

Asabiyet kavramı temel grup bilincini oluştururken bu kavramın aynı zamanda gruba kimlik kazandıran bir niteliği de vardır. Kişi hangi grup(lar)la birlikte dayanışma ve ortak bilince sahipse o kişi o gruba aittir. Kendisinin belirttiği gibi, "Birinin şunlardan veya bunlardan olması, o gruba ait hükümlerin onun üzerinde de geçerli olmasından başka bir anlamı yoktur" (İbn Haldun, 2015, s. 337). Demek ki herhangi bir kişinin grubunu belirleyen temel etken o kişinin biyolojik ailesinden öte sosyolojik ailesidir. Biyolojik aileden sosyolojik aileye ulaşan İbn Haldun'a göre biyolojik (nesebi) bağlar ancak sosyolojik (yardımlaşma ve dayanışmaya ilişkin) bağlarla birleştiğinde bir anlam ifade edebilir. Biyolojik bağ, temel olmakla birlikte bu bağın sosyolojik bağlarla desteklenmediğinde herhangi bir varlığından ve etkisinden de söz edilemez. Kaldı ki İbn Haldun nesep asabiyetinin sosyal yardımlaşma ve dayanışmadan da -genel olarak- ayrı düşünülemeyeceğini belirtmektedir. Yani soy bağı sosyal bağlarla iç içe ve birbirini destekler mahiyettedir.

Temel grup bilinci olarak karşımıza çıkan asabiyetin ilk hali insanları maddi/biyolojik varlıklar olarak görmenin yanında aynı zamanda onlanı psikolojik ve sosyal varlıklar olarak da görmemizi sağlar. İnsanın psikolojik ve sosyal varlığının temelinde asabiyet vardır. Dolayısıyla asabiyet, kan bağının veya onun yerine 
geçebilecek uzun ve birlikte yaşama, yüz yüze ilişkilerde bulunma, benzer hayat ve çevre şartlarını paylaşmanın meydana getirdiği, benzer niteliklere sahip her türlü sosyal birimde ortaya çıkan ve böyle bir grubun üyelerini birbirlerine sevgi, sorumluluk ve merhamet gibi bağları ve bilinci ile bağlayan bir dayanışma duygusudur denebilir (Arslan, 2014, s. 100).

İbn Haldun'un yaklaşımıla ifade edecek olursak, grup içindeki birey psikolojik/öznel bir varlığa sahipken grup dişındaki birey grubun bir üyesi olarak grubun kimliğini taşımaktadır. Birey ve grup arasındaki ilişki diyalektik olmakla birlikte esas olanın grup olduğu anlaşılmaktadır. Çünkü grup dayanışmanın ve yardımlaşmanın temel birimidir. Grup bireylerin toplamından farklı bir şeydir. Grubu bireyler oluşturur, fakat toplumu gruplar meydana getirir. Toplum karşısında bireyin varllğ̆ından söz edilemez. Toplum karşısında ancak grupların varlığından söz edilebilir. Cabiri’nin de belirttiği gibi, "asabeye içeriden baktığımızda onun belli bir "benlik "üzerine kurulduğunu ve yine içeriden baktığımızda asabe dâhilindeki her bir şahsın müstakil ve ayırt edici bir "benliğe", hatta kendine has bir şahsiyete sahip olduğunu görürüz. Fakat asabeye dışandan baktığımızda, orada tek bir "ben" buluruz, o da asabenin "ben"idir. Bu durumda asabeye ait olan "ben" asabedeki her bir ferdin de "ben"idir aynı zamanda. İster bir bütün olarak asabenin şahsiyetini temsil etmesi, isterse fertlerinden birinin şahsiyetini temsil etmesi itibariyle olsun, asabeye ait bu "ben"'in etkinliği, "asabiyet" diye adlandırllan şeyin bizzat kendisidir" (Cabiri, 2018, s. 211).

İbn Halduncu asabiyet kavramının ilk ve temel izdüşümünün toplumdaki soy ve kan bağıyla kurulan aile/akrabalık ilişkileri olduğu söylenebilir. Gerçekten de topluma baktığımızda aile tüm toplumların temel grubu/kurumu olma niteliğine sahiptir. Çünkü insan bir ailede doğmak ve yaşamak zorundadır. Toplumda kan ve soy bağı dışındaki hiçbir grup ailenin yerini tutamaz. Bu sosyolojik bir yasadır. Nitekim modern sosyoloji de ailenin toplumların temel, evrensel ve zorunlu bir grubu/kurumu olduğunu kabul etmektedir.

\section{Milli Bilinç Olarak Asabiyet}

Asabiyetin ilk ve temel halinin nesep (soy/kan bağı) asabiyeti olduğuna yukarıda değinildi. İbn Haldun toplumu bir arada tutan nesep dışındaki farklı asabiyetlerin de farkındadır. Kendisi bu olguyu "sebep asabiyeti" olarak kavramsallaştırır. Ona göre, "bir soydan gelmeseler bile, insan doğasında yardımlaşma ve birleşme özelliği mevcuttur. (...). Kent sakinlerinin çoğu, sıhriyet (evlilik-hısımlık) yolu ile birbiriyle kaynaşmışlardır. Bu yolla birbirine o derece bağlanırlar ki, birbirlerinin eti kemiği ve akrabası olan çeşitli gruplar meydana getirirler. Kabileler ve aşiretler arasında var olan cinsten düşmanllğın ve dostluğun bir benzeri bunlar arasında da görülür. Dolayısıyla bunlar da topluluklar ve asabeler şeklinde çeşitli fırkalara ayrilırlar" (İbn Haldun, 2015, s. 684).

Sebep asabiyetlerinin en önemlilerinden biri ulusları meydana getiren ve onun temelini oluşturan milli bilinç olarak karşımıza çıkmaktadır. Bugün yeryüzünde bulunan irili ufaklı etnik toplulukların temelinde dil, kültür ve coğrafya birlikteliğinden oluşan milli bilinç asabiyeti vardır. Milletlerin devletleşmesi ise asabiyetin gücüyle doğru orantlıdır. Devletleşmeyen milli asabiyetler de mevcuttur. Söz gelimi günümüzde Türk, Arap, İngiliz, Rus vb. uluslar devletleşmiş milli asabiyetlerdir. Bunların dışında devletleşmemiş fakat kendi dil, kültür ve coğrafyasında bölgesel olarak varllğını sürdüren etnik/milli asabiyetler de vardır. İbn Haldun'un belirttiği gibi, “Asabiyetler birbirilerinden farklıdır. Her asabiyetin, etrafindaki kavim ve aşireti üzerinde bir egemenliği vardır. Bununla birlikte her asabiyetin mülkü bulunmamaktadır." (İbn Haldun, 2015, s. 417). Tüm ulusal toplulukların temelinde asabiyet vardır. Her ulusun egemenlik sınırları vardır. Günümüzdeki ülkelerin sınırlarını tayin eden esas faktör İbn Halduncu bakış açsısından milli asabiyetlerdir. Kendisinin ifadesiyle; "söz konusu en güçlü asabiyet için, kendi kabilesi üzerinde galip gelme ve egemenlik kurma durumu ortaya çıkınca, doğası gereği kendisinden uzak olan diğer asabiyetler üzerinde de egemenlik kurmak ister. Eğer üzerinde egemenlik kurulmak istenen asabiyet, egemenlik kurmak isteyen asabiyetin dengi veya onun egemenlik kurma isteğine karşı koyacak güçte ise, artık ortada birbirine denk iki savaşçı güç ve eş kuvvete sahip iki hasım var demektir. Bunlardan her biri, kendi bölgesi ve topluluğu üzerinde bir egemenliği bulunur. Dünyadaki çeşitli milletlerin ve toplulukların durumu budur" (İbn Haldun, 2015, s. 350).

Milli bir bilinç anlamında asabiyetin, temel grup ruhu ve bilinci olarak ortaya çıkan asabiyetten fark1, ailenin bireylerden; milletlerin ise benzer dil, tarih ve coğrafya ortaklı̆̆na dayanan ailelerden oluşmasıdır. 
İbn Haldun'un yaklaşımına göre sonuçta toplum bireylerden değil, gruplardan oluşmaktadır. Bu grup topluluğunun üst birliklerinden biri de milli topluluklardır. Bu açıdan bakıldığında asabiyet, oluşmuş bir toplumun en temel bağlarına ve diğer toplumlar söz konusu olduğunda onun kendine özgü kimliğine işaret etmektedir (Gültekin, 2016, s. 284). Böylece milli asabiyetler uluslar asındaki fark ve sınırı oluşturmaktadır. Milli asabiyetlerin nesep asabiyetinin makro düzlemdeki karşıllğını ifade etmekte olduğu belirtilebilir. Başka bir ifadeyle nesep asabiyeti belirli bir aile ve akraba topluluğuna karşıllk gelirken, milli asabiyet bu aile ve akraba topluluklarının bir toplum/millet haline dönüşmüş halini ifade etmektedir. İbn Haldun, asabiyetin varlı̆̆ının veya göreli yokluğunun bir toplumun doğasını diğerinkinden ayıran en önemli özelliğini oluşturduğuna inanır (Dale, 2018, s. 47). Milli asabiyetler ulusları meydana getirir. Bu açıdan kavram bir his veya varsayım değil, toplumsal düzenin maddi, duygusal ve ideal gerçekliklerini saran bütüncül bir olgudur. Bir merkezi olup çevreye doğru yapılanan toplumun genel ve dinamik bir varllğıdır (Gültekin, 2016, s. 291).

İbn Halduncu asabiyet kavramının sosyolojik izdüşümlerinden birinin aileleri üst bir kimlikte bir arada tutan, dil, kültür ve coğrafya birlikteliğine dayanan ve milletleri meydana getiren milli bir bilinç olarak ortaya çıktı̆̆ ifade edilebilir. Milli bilinç olarak asabiyet, nesep asabiyetinin makro tipi olarak anlaşılabilir.

\section{Dini (ideolojik) Bilinç Olarak Asabiyet}

Her türlü din, ideoloji, felsefe vb. düşünsel manevi inanç ve değerler toplumsal hayatın ortak unsurlarındandır. Bu bağlamda toplumsal inanç ve değerler de bir asabiyet (birleştirici unsur) oluşturmaktadır. İnancın gücü ve yoğunluğu toplumsal birlik, beraberlik ve başarının ana bileşenlerinden biridir. Toplumsal inanç ve değerlerin asabiyet oluşturma gücü, toplumun bunları benimseme gücüyle doğru orantıllıdır. İbn Haldun bu hususu şöyle ifade etmektedir: "Dini unsur, asabiyet sahipleri arasında var olan çekişmeyi ve kıskançlığı giderir, yönlerini yalnızca Hakk'a çevirir. Böylece, kendileri hakkında ileriyi görme durumu ortaya çıkt $\mathrm{m}$, artı önlerinde kimse duramaz, nitekim hedef aynıdır, aynı şeyi herkes eşit bir şekilde istemekte ve aynı hedef için canlarını feda etmektedir" (İbn Haldun, 2015, s. 378). "Aynı durumu dini niteliğin değiştiği ve bozulduğu duruma da uygulayınız. Bu durumda egemenlik çözülmekte, dinin getirdiği ek bir unsur olmaksızın galibiyet sadece asabiyet düzeyinde olmaktadır" (İbn Haldun, 2015, s. 379).

Toplum bir asabiyetler bileşkesidir. Din veya ideoloji bu bileşkenin dayanışma ve yardımlaşma yapısını etkileyen en önemli faktörlerden biridir. İbn Haldun'un belirttiği gibi, “dini birleşme, ölümü severek göze alma ve feraset sahibi olma imkânını vererek onların asabiyetle ilgili güçlerine güç katmıştır" (İbn Haldun, 2015, s. 379). İbn Haldun, üyeleri dini bir ideali paylaşan bir topluluğun karşısında hiçbir şeyin duramayacağını savunur (Dale, 2018, s. 200).

Dinin toplumsal dayanışmadaki temel işlevi toplumu manevi amaç etrafında birleştirmesinden ileri gelmektedir. Bu birleştirme her türlü sosyal farklılıkları arka plana itmekte, bunun yerine manevi hedefleri toplumun önüne koymaktadır. Herhangi bir toplumdaki dinin ortak bilinç fonksiyonu yeni bir asabiyetin oluşumuna da zemin hazırlar. Böylece, ortak inanç, topluluklar içerisindeki hizipçi duyguları köreltir ve kabile üyelerini dava uğruna ölmek için yüreklendirir (Dale, 2018, s. 200). Dolayistyla din veya ideoloji birliği de toplumsal dayanışma türlerinden biridir.

Asabiyetin sosyolojik izdüşümlerinden birinin din veya ideoloji olduğu rahatlkla gözlemlenebilir. Dini veya ideolojik birlik ve beraberliğin bulunmadığı toplumlardaki dayanışmanın son derece zayıf olduğu söylenebilir. Dinden arınmış bir asabiyet, birleştirici olabilmek bir yana, bölücü ve hatta parçalayıcı dahi olabilir. İbn Haldun açısından din veya o anlamdaki herhangi bir ideolojinin asabiyetin temel unsurlarından biri olduğu söylenebilir (Kayapınar, 2006, s. 105). Demek ki İbn Halduncu asabiyet kavramının sosyolojik izdüşümlerinden biri de dini (ideolojik) bilinçtir. Bu anlamdaki bilincin toplumsal yoğunluğu farklı olmakla birlikte bunu her toplumda gözlemlemek mümkündür.

\section{Siyasi Bilinç Olarak Asabiyet}

Asabiyet kavramının sosyolojik izdüşümlerinden biri de siyasi bilinç olarak karşımıza çıkmaktadır. İbn Haldun'a göre bir toplumda iktidarı/hükümeti belirleyen en önemli faktör asabiyettir. Tüm toplumsal bağlarda olduğu gibi siyasi bağlarda da bir bilinç (asabiyet) olmazsa olmazdır. Devlet, bu anlamda, biyolojik 
bir birliktelik olmayıp, manevi bir birlikteliktir. Devleti oluşturan da bu bilinçtir. Bu bilincin dişında kalan bağlann gerçekten var olup olmadı̆̆1 konusu ise ikinci derecede önemlidir (Kaynar \& Ak, 2018, s. 187). İbn Halduncu çözümlemede asabiyet siyasi birlik ve otoritenin de asıl kaynağıdır.

Her insan toplum içinde doğar ve toplum içinde yaşar. Bu, toplumsallığın temel yasasıdır. İbn Haldun’a göre, toplumsal hayatın temel ilkelerinden biri de, toplum içinde insanın insana olası bask1 ve haksızlıkları önleyecek güçlü bir otoriteye olan ihtiyaçtır. Bunun toplumdaki karşıllğı devlet olgusu/kurumudur. İbn Haldun'un ifadesiyle, "İnsan doğası gereği toplumsal hayatta her zaman, insanların birbirlerine olan tecavüzlerini önleyecek bir otoriteye ihtiyaç duyar. O halde belli bir iktidarın, söz konusu asabiyetle diğerlerine galip gelmesi gereklidir" (İbn Haldun, 2015, s. 350). Demek ki her toplumda siyasi bir iktidar/otoritenin bulunması toplumsal bir zorunluluktur. Siyasi iktidarın oluşumunun kaynağında ise o toplumun asabiyet yönünden en güçlü olanının (siyasi bilinci en güçlü olan topluluğun) iktidar1 ele geçirmesi olayı vardır. Yine kendisinin ifadesiyle, "topluluk ve asabiyet, oluşma durumundaki bir şeyin mayası gibidir. Oluşma halindeki bir şeyde mevcut olan unsurlar kuvvet ve üstünlük bakımından birbirine denk olsalar, mizaç o şeyin vücuda gelmesini sağlamaz. O halde mutlaka unsurlardan birinin öbürlerine egemen olması gerekir. Aksi halde oluşum tamamlanmaz. Asabiyette galibiyetin esas kılınmasının sırrı ve hikmeti de budur. Değindiğimiz gibi yönetimin, kendine has nisapta devam etmesi meselesi de bu şekilde belirlenmiş olur" (İbn Haldun, 2015, s. 338-339).

Her siyasal otoritenin temelinde o otoritenin yaslandığ1 toplumsal taban vardır. Devletin başlang1c1 asabiyete dayanmaktadır (İbn Haldun, 2015, s. 388). Toplumsal destek siyasal otoritenin ana kaynağıdır. Bu yüzden, yönetimin kime geçeceğini, asabiyetle vücuda gelen galibiyet belirler (İbn Haldun, 2015, s. 339). Demek ki toplumsal hayatta var olan siyasal iktidann kaynağını da as abiyet oluşturmaktadır. İbn Haldun'a göre insan topluluklarında devlet şeklinde örgütlenmeyi mümkün kilan etken asabiyettir (Say, 2014, s. 138). Devlet, İbn Haldun'da, herhangi bir asabiyete ait hâkimiyetin mekânsal ve zamansal uzantısıdır (Cabiri, 2018, s. 263). Toplumdaki en güçlü asabiyet siyasal iktidarı ele geçirir (İbn Haldun, 2015, s. 388).

Asabiyet bir topluluk veya bir grup insanın ilişkilerini pekiştirir. Ancak insanların sayısında bir artış olduğunda, grubun asabiyeti iktidar grubu içerisinde bir muhalefetten dolayı zamanla sarsılabilir; çatışan bağlılıklar iktidar mücadelesine yol açmasından dolayı sarsılabilir. Böylece dayanışma duygusuna sahip olan en güçlü alt grup, zayıf dayanışma ve kuralları olan diğer alt gruplara zorla ve bastırmayla üstün gelebilir. Demek ki, bir grubun asabiyeti ne kadar güçlü olursa diğer grupları yönetme ve onlara egemen olma şans1 da daha yüksektir. Bu, doğaldır, çünkü tıpkı doğal bedeni oluşturan unsurlar gibi güçlerin denkliği uyumlu bir yapı oluşturamaz (Mohammad, 2017, s. 239).

İbn Haldun'a göre asabiyet ile iktidar arasında doğrudan bir ilişki söz konusudur. Herhangi küçük bir grup içerisinde de, bütün bir toplumda da siyasal egemenliği ele geçirecek güce sahip olmak, iktidarı ele geçirmek ve onu sürdürmek için mutlak surette asabiyete ihtiyaç vardır. Siyasal anlamda eyleme geçmenin asgari şartı olan birlik ve beraberlik ancak asabiyet ile kendini gösterebilir. Herhangi bir topluluk üzerinde egemenlik ya da bir toplum üzerinde hâkimiyet sağlamak güc'e dayanarak gerçekleştirilebileceğine göre, mücadele-çatışma-savaş gibi “aksiyona geçme”nin daha etkin biçimleri de asabiyetin varlı̆̆1 ve gücü ile orantilidir (Hassan, 2015, s. 207).

Devleti/iktidan diğer sosyal/siyasal birliklerden ayıran temel özelliklerin başında grubun, ordu, vergi, yasama, yürütme ve güç/baskı tekeline sahip olması gelmektedir. Siyasal iktidarın/devletin ana nitelikleri bunlardır. Herhangi bir siyasal grubu (partiyi) devlet haline getiren şeylerin başında, o grubun adı geçen niteliklere sahip olması gelmektedir. İbn Haldun'un belirttiği gibi, "Hakiki manada mülk, sadece halk1 yönetimi altında tutan, mal ve vergi toplayabilen, elçiler gönderen, sınırları koruyabilen ve gücünün üstünde başka bir güç bulunmayan asabiyete aittir. Mülkün meşhur anlamı, hakikati ve gerçekliği budur” (İbn Haldun, 2015, s. 417). Asabiyet, İbn Haldun için bir grubun başka bir grup üzerinde otoritesini kurması ve giderek devletin oluşturulması olayının özündeki ana etkendir (Arslan, 2014, s. 100). Dolayısıyla İbn Halduncu açıdan bakıldı̆̆ında her devlet/iktidar bir asabiyete dayanmakla birlikte her asabiyet devlet/iktidar demek değildir. 


\section{Küresel Bilinç Olarak Asabiyet}

Buraya kadar grup ve toplum ekseninde ortaya çıkan asabiyet çeşitleri incelendi. Bu başlikta ise, toplumlar arası ve üstü sayılabilecek olan küresel asabiyet üzerinde durulacaktır. Küresel asabiyet kavramsallaştırması günümüz uluslararası ilişkileri anlama ve açıklamada analitik bir kavram olarak kullanılabilir. Günümüzde uluslararası ilişkilerde birçok bloktan söz edilmektedir. Bu bloklar ekonomik temelli olabileceği gibi, siyasi ve ideolojik temelli de olabilir. Bu uluslar üstü toplumsal birliklerin anlaşılabilmesi noktasında küresel bir bilinç olarak asabiyet pekâlâ kullanılabilir. Nitekim insan ve toplum doğasının çok boyutlu yansıması olan asabiyet, zaman içinde yeni ihtiyaç tanımlarına dayalı olarak farklı bireysel tipolojiler ve toplumsal yapılar şeklinde karşımıza çıkabilir (Gültekin, 2016, s. 285). Küresel asabiyet", 'nesep asabiyeti"ndeki soy ilişkisinden kaynaklanan kabile ve akraba bağı yaklaşımının ötesindedir. Bu durum 'kan bağı'nı aşar (Korkusuz, 2010, s. 486). Küresel asabiyet toplumlar arasındaki dil, din, ideoloji, kültür, siyasi, ekonomik vb. ilişkileri ihtiva etmektedir. Adı geçen unsurlar etrafinda bir araya gelen toplumlar belirli bir asabiyeti teşkil etmektedirler. Böylece asabiyet sosyolojik düzlemde küresel bir bilinç olarak karşımıza çıkabilmektedir (Korkusuz, 2010, s. 461).

Daha önce her asabiyetin sürekli büyümek ve genişlemek gibi bir hedefinin varlığından söz edilmişti. Aslında küresel asabiyet kavramı, herhangi bir yerel asabiyetin büyümesi ve genişlemesinden başka bir şey değildir. Genişleme kendine denk bir asabiyetle karşılaştı̆̆ında egemenlik sınırı oluşur. Her asabiyetin maksimum büyüme ve genişleme hedefi vardır. Ulusal sınırları aşan asabiyetler küresel asabiyet konumuna yükselirler.

Bir kere bir grup içinde üstün dayanışma meydana geldiğinde, bu, daha zayıf dayanışmaları bastırmaya ve onları kontrol altına almaya yönelir. Neticede, çatışan taraflanı birleştiren ve onların enerjilerini diğer gruplarla mücadeleye ve onları bastırmaya yönlendiren daha büyük bir dayanışma (asabiyeti kübra)'dır. Genişleme ve birleştirme süreci, yeni kurulmuş bir dayanışmanın diğer devlet veya devletlerin hâkimiyetlerini ele geçirmesine varıncaya ya da yeni şehirler kuruluncaya kadar böylece devam eder (Mohammad, 2017, s. 239).

En güçlü asabiyet, kendi kabilesi üzerinde egemenlik kurunca, doğası gereği kendisinden uzakta olan diğer asabiyetler üzerinde de egemenlik kurmak ister. Ĕger egemenlik kurulmak istenen asabiyet, egemenlik kurmak isteyen asabiyetin dengi olur veya onun egemenlik kurma isteğine karşı duracak kuvvette ise, artık ortada birbirine denk iki savaşçı güç ve eş kuvvete sahip iki taraf var demektir. Bunlardan her birinin, kendi bölgesi ve kavmi üzerinde bir egemenliği bulunur. Dünyadaki çeşitli milletlerin ve kabilelerin durumu buna örnektir (İbn Haldun, 2015, s. 350).

Kısaca asabiyet kavramının küresel ölçekteki karşılığı ve sosyolojik izdüşümü küresel asabiyettir denebilir. Bu asabiyet toplumlar arasındaki karşılıklı güç, koalisyon ve bağımlılık ilişkilerini ifade etmektedir.

\section{Toplumsal Düzenin Sağlayıcısı Olarak Asabiyet}

Toplum dediğimiz olgunun kendine has bazı özellikleri vardır. Bunlardan biri de toplumsal hayatın istikrarlı ve sağlıklı bir şekilde işlemesi, yani düzendir. Her ne kadar toplumda çeşitli nedenlerden dolayı bazı çatışmalar yaşansa da toplumsal hayatta asıl olanın düzen olduğunu belirtmek gerekir. İbn Haldun toplumsal hayatta ortaya çıkabilecek bazı çatışma ve haksızlıkları önleyici bir mekanizmanın varlığının kaçınılmaz olduğunu düşünür (İbn Haldun, 2015, s. 350). İşte bu toplumsal düzenin sağlayıc1 gücü ve aktörü asabiyettir. İbn Haldun'un bahsettiği yasaklayıcı güç unsurunun, genel olarak, özelliklerini baskın toplumsal hayattan alan sosyal bir otorite olması (devlet) anlamında bir toplumsal müeyyideyi ifade ettiği söylenebilir (Cabiri, 2018, s. 203). Toplumsal düzeni sağlayıcı mekanizma devletten başka bir şey değildir.

İbn Haldun'da devlet toplumsal düzeni sağlayıcı kurumudur. Daha önce de ifade edildiği gibi, her devletin arkasında güçlü bir asabiyetin olması gerekmektedir. Bu analizlerden devlet ve hükümet ayrımına ulaşabilmekteyiz. İbn Halduncu bakşs açısından devlet bir olgu ve ana işlevi düzeni sağlamak iken, hükümetler birer olay ve devlet erkini kullanan sosyal aktörlerdir. Ancak her ikisinin de dayandiğı toplumsal güç asabiyettir. Toplumsal düzenin sağlayıcısı olarak asabiyet ile siyasi bilinç olarak asabiyet arasındaki temel farkın, ilkinin temel işlevinin düzen, ikincisinin ise iktidar olduğu ifade edilebilir. İbn 
Haldun'daki sosyal düzen vurgusunun toplumdaki karşıllığ kuşkusuz devlet kurumudur (İbn Haldun, 2015, s. 388).

Toplum gruplardan oluşmaktadır. Gruplar birbirine denk olursa devletin (hükümetin) oluşumu gerçekleşemez. Devlet, kaynağını toplumsal eşitsizliklerden alır. Toplum eşitsiz gruplardan oluştuğundan, bu eşitsiz yapıyı düzenleyecek ve denetleyecek olan kurum devlettir. Bu açıdan bakıldığında asabiyet (devlet) toplumsal düzenin sağlayıcı kurumu olarak karşımıza çıkmaktadır.

\section{Toplumsal Değişmenin Kaynağı Olarak Asabiyet}

Toplumda düzen asıl olmakla birlikte toplumsal değişmenin gerçekleşmesi de asabiyete bağlıdır. Değişme de düzen gibi toplumsal bir olgudur. Düzeni sağlayan asabiyet olduğu gibi, değişimin kaynağı da asabiyettir. Demek ki asabiyet durağan ve tekdüze bir olgu olmayıp, aksine son derece dinamiktir. Toplumdaki her grup kendi istek ve hedeflerini gerçekleştirmek ister. Bu hedeflerin nihai noktası topluma egemen olmak ve iktidarı ele geçirmek şeklinde tezahür etmektedir. Dolayısıyla gruplar (asabiyetler) arasındaki çatş̧malar toplumsal değişmenin kaynağını teşkil etmektedirler. Sonuçta toplumsal değişmenin kaynağını da asabiyet oluşturmaktadır (İbn Haldun, 2015, s. 373).

Görüldüğü gibi, toplumda farklı çıkar ve amaç grupları vardır. Tüm toplumsal gruplar diğer gruplara egemen olma ve onları yönetme gibi bir hedef taşıyabilirler. Ancak bu hedefi gerçekleştirme ve toplumu değiştirme asabiyete bağlıdır. İbn Haldun, değişimi bir tek faktörle açıklar: Asabiyet. (...). İbn Haldun bu kavramı, değişimi sistemdeki diğer tüm dinamiklerle bağlantılı olan dâhilî bir değişken olarak inceler (Kayapınar, 2006, s. 86). Bu noktada asabiyet toplumsal değişmenin ana kaynağı olarak karşımıza çıkmaktadır.

Düzen ve değişme diyalektik bir süreçtir. Her düzen değişmeyi her değişme düzeni içinde barındırır. Ancak her iki durumda da ana aktör asabiyettir. Asabiyet olmadan ne düzen ne de değişme gerçekleşebilir.

\section{Sonuç}

Sosyal bilimsel kavramlar yapıları gereği çok anlamlı olabilirler. Örneğin kültür, din, yabancılaşma, anomi, sekülerleşme vb. kavramlar birden fazla anlam ihtiva ederler. Bunlar gibi İbn Haldun'un asabiyet kavramı da çok anlamlı kavramlar sınıfina girer.

İbn Haldun'un asabiyet kavramı özünde kan ve soy bağına dayalı bir toplumsallık bilinci-duygusu olsa da bu kavram aynı zamanda içeriği ve yoğunluğu değişen her türlü toplumsal bilinç ve eylemliliğin temel unsurunu ifade etmektedir. İbn Haldun bu kavramı toplumsal hayatn ve olguların merkezine koyar. Bedevilikte temel öneme sahip asabiyet olgusu, farklı toplumsal gruplarda dönüşüme uğrayarak varllğını sürdürür. Yukarıda da belirtildiği gibi kavram, toplumsal hayatta farklı bilinçler olarak kendini göstermektedir.

Her grup belirli bir asabiyete sahiptir. Bu asabiyet ya kan/soy bağına dayanmakta ve/veya inanç, çıar, amaç vb. birlikteliklere dayanmaktadır. Gruplar birliği toplumu, toplumlar birliği de küresel toplumu meydana getirir. Bu kaçınılmaz bir olgudur. Başka bir ifadeyle, her insan bir grup içerisinde, her grup bir toplum içerisinde her toplum da küresel bir yapı içerisinde yaşamak zorundadır denebilir. Bu asabiyetler arasında işbirliği ve dayanışma olabileceği gibi, çatışma ve rekabet de olabilir.

Her sosyal bilimsel kavramda olduğu gibi, İbn Halduncu asabiyet kavramını da sabit bir anlamda dondurmak veya her tür tanıma sığdırmak doğru değildir. Ancak bu, kavramın açılamak istediği olguları belirlemeye de mani olmamalıdır. Bu çalışmada İbn Haldun'un Mukaddime adlı eserinde üzerinde sıkça durduğu ve geniş bir açıdan ele aldığı asabiyet kavramının sosyolojik izdüşümlerine 1şık tutmaya çalıştık.

Bir kavramın sosyolojik izdüşümlerinden hareketle bir asabiyet tipolojisine ulaşilan bu çalş̧mada son olarak şu da belirtilmelidir ki, farklı toplumsal tezahürleri olan asabiyet olgusu toplumda tüm gruplarda eşgüdüm halinde faaliyet göstermektedir. Söz gelimi milli bilinç olarak asabiyet, dini (ideolojik) bilinç olarak asabiyeti etkilediği gibi, dini (ideolojik) bilinç olarak asabiyet de siyasi bilinç olarak asabiyeti etkiler. Sonuçta İbn Halduncu açıdan bakıldığında toplum denen olgunun, çoklu asabiyetlerden meydana geldiği ve bunların karş̧lıklı olarak birbirlerini etkilemekte olduğu ifade edilebilir. Nihayet asabiyet, modern sosyolojik anlayışta, her türlü insan birlikteliğinde yansıması olan bir grup dinamiğidir, denebilir. 


\section{Extended Abstract}

The scientific way of understanding social facts and events is through creating empirical concepts. In this respect, modern sociology has developed various concepts, theories and approaches to understand and explain social phenomena. For example, society, group, institution, collective consciousness, culture, religion and so on. The ultimate goal of all these social scientific concepts is to understand and explain the phenomenon we are in and call society. All social scientific concepts can be constantly redefined and given new meanings to them.

Here, how a concept (asabiyya) is used in different meanings and contexts in a work (Muqaddime) will be discussed. The aim of this study is to try to reveal a typology of asabiyya based on the sociological projections of Ibn Khaldun's concept of asabiyyah. Asabiyet constitutes the basis of social solidarity in Ibn Khaldun. As he stated, "Protecting, defending and seeking rights for each other can only be possible with irritability. This also applies to all kinds of collective social activities. Therefore, asabiyyah theory is a theory that has a very wide domain and many components. Experts agree that Ibn Khaldun redefines asabiyya by attributing different meanings. He describes asabiyya sometimes according to its benefit and sometimes according to its purpose, shows its source, tries to determine its types, especially draws attention to its importance. He accepts the existence of different asabiyya in various social groups such as the groups he has formed. Thus, asabiyya emerges as a social principle in a broad sense.

The concept of asabiyya, which has an important place in Ibn Khaldun's social theory, is undoubtedly one of the concepts that Ibn Khaldun's researchers have studied the most. However, the multidimensional meaning he gives to this concept may present some difficulties in expressing it with the concepts used by modern social sciences. Although contemporary researchers generally try to explain this concept with the concepts of social solidarity or solidarity, we should state that this refers to only one dimension of the concept of asabiyya. Because of the meanings of "racism or tribalism" expressed by the concept in the period before Islam, this concept has been evaluated as a more negative concept in Islamic culture; especially Muslim scholars interpreted asabiyya as a virtue because Muhammad criticized and rejected asabiyya, which means tribalism, with a strict language.

Ibn Khaldun, as a thinker who lived in the 14th century, focused on a concept that has various meanings and functions in terms of understanding and explaining the society in his book Kitab'ul-Iberi, which he wrote in 1377: Asabiyya. Ibn Khaldun successfully used this concept in understanding different social facts and events. Here, from the perspective of Ibn Khaldun, the sociological projections of the meaning and functions that the concept of asabiyya has at the point of understanding the society will be emphasized.

Social scientific concepts can be very meaningful due to their nature. For example, culture, religion, alienation, anomie, secularization, etc. concepts contain more than one meaning. Like these, Ibn Khaldun's concept of asabiyyah falls into the class of very meaningful concepts. Ibn Khaldun's concept of asabiyya is essentially a consciousness-sense of sociality based on blood and descent, as well as changing the content and intensity of the concept, becoming the basic element of all kinds of social consciousness and agency. Ibn Khaldun puts this concept at the center of social life and facts. The asabiyyah phenomenon, which is of fundamental importance in Bedouin, continues its existence by transforming in different social units and societies. As stated above, the concept manifests itself in different consciousness structures in social life.

Each group has a certain irritability. This irritability is either based on blood / descent and / or belief, interest, purpose, etc. It is based on togetherness. The union of groups constitutes society, and the union of societies constitutes the global community. This is an inevitable phenomenon. In other words, it can be said that every person must live in a group, every group in a society, and every society in a global society. There may be cooperation and solidarity among these asabiyyahs, as well as conflict and competition. As with every social scientific concept, it is not correct to freeze the Khaldunian concept of asabiyyah or to fit it into certain definitions. However, this should not prevent determining the facts that the concept wants to explain. In this study, we tried to shed light on the sociological projections of the concept of asabiyet, which Ibn Khaldun frequently emphasizes in his work named Muqaddima and which he discusses from a broad perspective.

Keywords: Ibn Khaldun, Asabiyyah, Collective consciousness, Group, Society 


\section{Kaynakça}

Arslan, A. (2014). İbn Haldun, İstanbul: İstanbul: Bilgi Üniversitesi Yayınlar1.

Batur, B. (2019). Bilim Taribinde Bir Dönemę̧: İbn Haldun'da Sosyal Bilim Düşüncesinin Doğuşu, Antakiyat 2/1, 90-115.

Cabiri, M. (2018). İbn Haldun'un Düsüncesi Asabiyet ve Devlet. çev: Muhammet Çelik, İstanbul: Mana Yayınlar1.

Dale, S. F. (2018). İbn Haldun ve İnsan Bilimi, çev: Ayşecan Ay, Canan Coşkan, İstanbul: Say Yayınları.

Demircioğlu, A. (2015). İbn Haldun'un Insan Dü̧̈üncesi ve Medeniyet Algısı, Ankara: Gece Kitaplı̆̆1 Yayınlar1.

Gültekin, M. (2016). İbn Haldun, Modernlik ve Modern Sosyoloji, The Journal of Academic Social Science Studies 51, 277-293.

Günay, Ü. (1986). Islam Dünyasinda Bir Din Sosyolojisi Öncüsü: İbn Haldun (1332-1406), Atatürk Üniversitesi İlahiyat Fakültesi Dergisi 6, 63-104.

Hasanov, B. (2016). İbn Haldun'da Asabiyet Kavram -Maurice Halbwachs'in "Kolektif Hafıqa” Kavramı İle Bir Karşılaștırma, Elektronik Sosyal Bilimler Dergisi 59, 1437-1446.

Hassan, Ü. (2015). İbn Haldun Metodu ve Siyaset Teorisi, İstanbul: Doğu Batı Yayınlar1.

İbn Haldun (2015). Mukaddime 1-2, çev: Süleyman Uludă̆, İstanbul: Dergâh Yayınları.

Kayapınar, A. (2006). İbn Haldun'un Asabiyet Kavramı: Siyaset Teorisinde Yeni Bir Açlım, İslam Araştırmaları Dergisi 15, 83-114.

Kaynar, M. K. \& Ak, G. (2018). Modern Siyaset Teorisinde İbn Haldun ve Asabiyet Düsüncesi, Akademik Sosyal Araştırmalar Dergisi 66, 177-195.

Korkusuz, M. H. (2010). 1980 Sonrası Milliyetçilik. Akımlarmın İbn Haldun'un Asabiye Modeli Bağlamında Değerlendirilmesi Yayımlanmamış Doktora Tezi, İstanbul: Marmara Üniversitesi Sosyal Bilimler Enstitüsü, İstanbul.

Mohammad, F. (2017). İbn Haldun'un Toplumsal Değişme Kuramı: Hegel, Marx ve Durkheim ile Bir Karşılaştırma, çev: Behçet Batur, Şırnak Üniversitesi İlahiyat Fakültesi Dergisi 17, 229-244.

Say, S. (2014). Uluslararası Siyaset Sosyolojisi Açısından İbn Haldun, Ankara: Detay Yayıncılık. Uludağ, S. (2015). İbn Haldun, Hayatı, Eserleri, Fikirleri, Ankara: Harf Yayınları. 